\title{
DIALEKTIKA AL-QUR'AN DENGAN POLA PIKIR KEBERAGAMAAN MASYARAKAT ARAB : Analisis Psiko-Sosial
}

\section{Syamsul Wathani}

Studi Qur'an Hadist, Pascasarjana UIN Sunan Kalijaga

Email: Wathoni89@gmail.com

\begin{abstract}
This article discusses the mindset of Arab society towards religion which is answered and it was changed after the Koran came. This relationship is dialectic, the arab community as khitāb al-Qur'an. The approach used by the social history of social psycho analysis. With this approach, this article found some important conclutions. (1) Social history emphasizes that geographic factors, psychological, and social culture have shaped their social siko. Psycho-social impact on their perspectives on God and Religion. God was related with a god (dewa) who can help the biological necessities of life, although not psychologically soothing. As the unsound of psico-social condition, the way they understand the religions is not correct. They profess religion, somehow does not feel the presence of God. The more they worship Gods, the more discrepancies, social injustices, and tyranny happen. Responding to that matter, the Quran apply persuasive method as the advice (al-din al-nașihah), and discussion (jidāl) as their way of thought on religion. (2) The Qur'an came alter their patterns of psychological evolution, from an-nafs al-ammara as bi-su' society into an-nafs al-lawwamah, until in the end they had a quiet soul (an-nafs al-Mutmainnah).
\end{abstract}

Keyword : social history, psycho-social, dialectic analysis, an-nafs al-ammärah, an-nafs allawwāmah, an-nafs al-muța'innah.

\section{Abstrak}

Artikel ini membahas pola fikir masyarakat Arab terhadap agama yang kemudian dijawab dan dirubah setelah al-Qur'an datang. Hubungan ini bersifat dialektis, 
dengan masyarakat arab sebagai khitāb nya. Pendekatan yang digunakan sejarah sosial dengan analisis psiko sosial. Dengan pendekatan ini, artikel ini menemukan beberapa muatan penting: (1) Sejarah sosial menekankan bahwa faktor geografis, psikis, budaya dan sosial telah membentuk psiko sosial mereka. Psiko-sosial berpengaruh pada cara pandang mereka terhadap tuhan dan Agama. Tuhan dkaitkan dengan dewa yang bisa membantu secara biologis kebutuhan hidup, walaupun tidak menenangkan secara psikis. Akibat psiko-sosial yang tidak baik, pola fikir mereka terhadap agama pun menjadi tidak baik. Mereka beragama, namun tidak merasakan kehadiran Tuhan. Bahkan semakin banyak dewa yang disembah, semakin banyak pula ketimpangan yang terjadi, ketidakadilan sosial, dan kezaliman. Menaggapi hal tersebut, al-Quran menggunakan metode persuasif berupa nasehat (ad-din an-nșihah) dan metode dakwah melalui debad (jidāl) dalam merubah pola fikir keberagamaan mereka. (2) Al-Qur'an datang merubah mereka dengan pola perubahan psikis, dari msayarakat an-nafs al-ammarah bi as-su' menjadi an-nafs allawwamah, hingga pada akhirnya mereka memiliki jiwa yang tenang (an-nafs almutmainnah).

Kata kunci: sejarah sosial, psiko-sosial, analisis dialektika, an-nafs al-ammärah, an-nafs allawwämah, an-nafs al-mutma'innah.

\section{Pendahuluan}

Banyak literarur sejarah yang menguatkan bahwa Nabi Muhammad saw. berhadapan dengan masyarakat yang sulit ditaklukkan, masayarakat Arab. Sebuah masyarakat yang memiliki karakter keras, memegang teguh ajaran nenek moyang dan ta'assub pada kesukuan. Al-Qur'an menyebut mereka sebagai kaum jăhiliyah, kaum yang jauh dari nilai-nilai humanis dalam menjalani kehidupan. ${ }^{1}$ Semenjak periode awal diwahyukan, al-Qur'an sudah dihadapkan pada sistem nilai dan kultur yang berjalan ini. ${ }^{2}$ Dan ditengah situasi ini pula Muhammad saw. diberikan tugas oleh Allah sebagai sesorang pemikir dan penggerak (man of action). ${ }^{3}$

${ }^{1}$ Dalam perspektif semantik, jahl yang di-maktūb-kan pada masyarakat Arab bukanlah antonim dari kata 'ilm (ilmu/berpengetahuan), melainkan antonim tetapi dari kata hilm (kesantunan). Dengan demikian, maka gelar (laqb) jahl yang ditujukan kepada masyarakat Arab menggambarkan pada pola perilaku khas seseorang yang bedarah panas-karena tandus, gersang secara geografis-, tidak sabar sehingga cenderung kehilangan kontrol diri. Bahkan sering terpancing dan terprovokasi oleh masalah yang sepele. Toshihiko Izutsu, Relasi Tuhan dan Manusia terj. Agus Fehri Husein (dkk.), (Yogyakarta: Tiara Wacana Yogya, 2003), hlm. 227.

${ }^{2}$ Mostofa Umar," Gradualisasi Turunnya al-Qur’an: Tinjauan Antropologi dan Psikologi Dalam Potret Pluralitas Budaya “, Jurnal Studi Ilmu-Ilmu Al-Qur'an dan Hadits, VI, Januari 2005, hlm. 2 .

${ }^{3}$ Asghar Ali Engineer, Islam dan Pembebasan (Yogyakarta: LKiS, 2007), hlm. 4. 
Sebagai core text peradaban Islam, ${ }^{4}$ al-Qur'an turun membawa ajaran, dimana masyarakat Arab menjadi khitāa pertamanya. Karena itu, tidak mengherankan jika kemudian banyak ditemukan dalam teks al-Qur'an nuansa dialektika antara al-Qur'an dengan kultur masyarakat Arab, baik bahasa maupun substansi ayatnya. ${ }^{5}$ Dialektika ini memberikan penjelasan bahwa realitas masyarakat Arab yang terjadi dan respon al-Qur'an terhadapnya menjadi alur penyampaian risalah Muhammad saw.

Diantara risalah pertama yang menajadi prioritas wahyu Muhammad saw adalah mengubah pola pikir masyarakat Arab terhadap agama, menuju tauhid. Dihadapkannya al-Qur'an pada pola pemikiran agama yang berjalan, membuat tauhid menjadi puncak tema pewahyuan. ${ }^{6}$ Tauhid yang menjadi ajaran utama risalahNya ini, kemudian diamanahkan kepada Muhammad saw. ketika umur beliau sudah menginjak 40 tahun. Dengan usia yang sudah matang seperti ini, jelas Nabi adalah orang yang sangat berpengalaman. Baliau adalah pribumi Arab yang mengetahui segala selub-beluk aspek kehidupan orang Arab. ${ }^{7}$

Agama adalah permasalahan esoterik, jiwa, dan kebutuhan batin. Sebelum menginjak umur 40 tahun, Nabi adalah orang yang merasakan pengalaman esoterik, dengan bertahannus di Gua. Pengalaman ini tentu menegaskan bahwa Nabi selalu mengamati psikologis aktual masyarakat Arab ketika. Pengalaman inilah yang kemudian menjadi modal utama dalam dakwah beliau. Jika sebelumnya beliau hanya bisa merenung dan berfikir, maka dengan datangnya wahyu, menjadikan hati beliau untuk tergugah melakukan tindakan nyata (action). ${ }^{8}$ Dalam tindakan ini, Muhammad saw. selalu melakukan dialektika, antara wahyu yang didapat kan dengan realitas yang dihadapi. Mencermati dialektika al-Qur'an sangat penting dilakukan. Agar dapat memahami secara cermat apa yang terjadi di masyarakat Arab ketika itu. Karena dialektika adalah sebuah proses yang hidup, bukan sebuah teks yang terbukukan, akan membuat kajian terhadapnya menghidupkan kembali pengabadian fenomena yang terekam dalam teks al-Qur'an. ${ }^{9}$

\footnotetext{
${ }^{4}$ M. Faisol Fatawi, Tafsir Sosiolinguistik: Memahami Hurf Muqata'ah Dalam al-Qur'an (Malang: UIN Malang Press, 2009), hlm. 3.

${ }_{5}^{5}$ Fahruddin Faiz, Hermeneutika Al-Qur'an: Tema-tema Kontroversial (Yogyakarta: eLSAQ Press, 2005), hlm. 99-100. 2004), hlm. 20

${ }^{6}$ M. Zuhri, Potret Keteladanan Kiprah Politik Muhammad Rasulullah, (Yogyakarta, LESFI,

${ }^{7}$ M. Zuhri, Potret Keteladanan Kiprah..., hlm. 19-20.

${ }^{8}$ Asghar Ali Engineer, Islam dan Pembebasan ... , hlm. 4.

${ }^{9}$ M. Faisol Fatawi, Tafsir Sosiolinguistik..., hlm. 83.
} 
Artikel ini akan mengarah pada pembahasan itu. Tema yang diangkat membahas dialektika al-Qur'an dalam mengubah pola pikir masyarakat Arab terhadap agama. Pendekatan yang digunakan adalah sejarah sosial. Sedangkan metode yang digunakan adalah eksploratif dengan analisis psiko-sosial. Ada beberapa pertanyaan yang hendak dijawab dalam artikel ini; Bagaima psikososial masyarakat Arab yang memeluk agama? Bagaimana sejarah sosial yang membentuk pola pikir masyarakat Arab terhadap agama? Bagaimana dialektika yang dilakukan oleh al-Qur'an dalam mengubah pola pikir masyarakat Arab terhadap agama?

Dengan pendekatan dan metode di atas, artikel ini diharapkan dapat memberikan penjelasan mengenai psiko-sosial masyarakat Arab sebagai sebuah realitas yang disapa oleh al-Qur'an. Agama sangat terkait dengan psikologi, dan psikologi sangat terkait dengan berbagai aspek realitas. Memberikan penjelasan mengenai sejarah sosial yang membentuk pola pikir masyarakat Arab terhadap agama. Menjelaskan mengenai dialektika hidup yang dialkukan oleh al-Qur'an dalam mengubah pola fikir masyarakat Arab terhadap Agama.

\section{Prespektif Sejarah Sosial dan Psiko-Sosial}

Semenjak diturunkannya, al-Qur'an sudah memainkan peran komunikatif (hiwar) dengan realitas. ${ }^{10}$ Celah kominikatif ini kemudian menjadi lahan penelitian al-Qur'an yang banyak menggunakan ilmu sosial humaniora. Dalam tradisi klasik, dialektika al-Qur'an ini dijadikan sub bahasan dalam ulüm' al-Qur'an yakni asbāb an-nuzūl. ${ }^{11}$ Bahkan beberapa pemikir sudah membuat teori tersendiri mengenai dialektika, seperti: dirāsah mā $\overline{f i}$ al-Qurān dan dirāsah mā hawla al-Qurán yang dicetuskan oleh Amin al-Khuli. ${ }^{12}$ Pada era selanjutnya, kajian dialektika al-Qur'an mulai berkembang. Ada yang memandang dialektika al-Qur'an menggunakan pola ilmu komunikasi, ${ }^{13}$ hingga ilmu kebudayaan (antropologi). ${ }^{14}$

${ }^{10}$ Navid Kermani "From Revelation to Interpretation; Nash Hamid Abu Zayd and The Literary Study of The Qur'an”, dalam Suha Taji-Farouki (ed), Modern Muslim Intellectuals an the Qur'an, (London: Oxford University Press, 2004), hlm. 171-172.

${ }^{11}$ Nasr Hāmid Abū Zaid, Mafhūm al-Nass: Dirāsat fī 'Ulūm al-Qur'ān (Beirut: alMarkaz alTsaqāî̀ al-Arabī, 2000), hlm. 25.

${ }^{12}$ Amin Al-Khuli dan Nasr Hamid Abu Zaid Metode Tafsir Sastra, ter. Khairon Nahdiyyin, (Yogyakarta: Adab Press, 2004), hlm. 64.

${ }^{13}$ A. Chaedar Alwasilah, Sosiologi Bahasa (Bandung: Angkasa, 1989), hlm. 7.

${ }^{14}$ Ali Sodiqin, Antropologi Al-Qur'an: Model Dialektika Wahyu dan Budaya, (Yogyakarta: Ar-Ruzz Media, 2008), hlm. 39-40. 
Fakta bahwa al-Qur'an diturunkan dalam realitas yang hidup, ${ }^{15}$ membuat kajian sejarah sosial mengenai masyarakat tempat ia diturunkan menjadi salah satu bagian penting. Sejarah sosial merupakan disiplin keilmuan yang membicarakan mengenai masyarakat. ${ }^{16}$ Karena studi nya sejarah, maka sejarah sosial menjadi cabang kajian. Ilmu sejarah sangat luas, tergantung obyek yang ingin diteliti. Sejarah memiliki core study pada kajian mengenai masa lampau, akan tetapi core ini masih menjadi studi umum. Munculnya core study yang lebih spesifik pada beberapa item kajian, menjadikan kajian sejarah berkembang pada item-item yang lebih terarah dan fokus. Seperti; sejarah politik (political history), sejarah ide (history of idea), sejarah ekonomi (economical history) dan lain sebagainya. ${ }^{17}$

Pendekatan sejarah sosial yang dimaksudkan dalam artikel ini mengambil obyek masyarakat Arab, pra, ketika dan pasca al-Qur'an diturunkan, dan sejarah masyarakat Arab (local history) sebagai fokus arah kajian. ${ }^{18}$ Dengan pendekatan ini, maka poin yang menjadi core penelitian adalah sejarah sosial masayarakat Arab, seperti; problem sosial, kondisi ekonomi-sosial, psikologi masyarakat, interaksi masyarakat, struktur sosial dan dimensi masyarakat lainnya. Dengan analisis pada sub poin diatas, diharapkan akan dapat memahami psikologi sosial masyarakat Arab, pola fikir masyarakat Arab terhadap agama, serta faktor-faktor kehidupan yang mempengaruhi.

Seperti halnya sejarah sosial, psiko-sosial lebih kepada melihat bahasa al-Qur'an dalam hubungannya dengan keadaan psiko sosial masyarakat. Jika psikologi sifatnya pribadi, maka psiko-sosial mengambil obyek yang lebih luas. ${ }^{19}$ Jika itu berkaitan dengan teks, psiko-sosil biasanya dijadikan pertimbangan penting. Dalam mempertimbangkan konteks khitāb. Sehingga bahasa dan muatan yang terkadung didalamnya tersebut tidak hilang dari konteks awal muncul, dan konteks awal dituju. ${ }^{20}$

Az-Zarqāni menje laskan bahwa diantara uslūb nya, gaya tutur al-Qur'an terkadang lansung menyentuh aspek psikologis. ${ }^{21} \mathrm{Al}-\mathrm{Qur}$ 'an adalah fenomena kebahasaan yang hadir dalam keadaan manusia yang bersosialisasi, berbudaya

\footnotetext{
${ }^{15}$ Mostofa Umar, “ Gradualisasi Turunnya Al-Qur’an ..., hlm. 2.

${ }^{16}$ Akh Minhaji, Sejarah Sosial dalam Studi Islam: Teori, Metodologi, dan Implementasi (Yogyakarta: Suka Press, 2013), hlm. 43.

${ }^{17}$ Akh Minhaji, Sejarah Sosial ..., hlm. 43.

${ }^{18}$ Ibid., hlm. 48-51.

hlm. 2

${ }^{19}$ Jean Caron, an Introduction to Psycholinguistics (London, Harvester Wheatsheaf, 1992),

${ }^{20}$ Jean Caron, an Introduction to Psycholinguistics, Hlm. 1-2

${ }^{21}$ Muhammad 'Abdul-Azim az-Zarqani, Manahilul-'Irfan fi 'Ulum al-Qur'an, (Beirut: Dar al-Kutub al-Arabi, 1995), II:243-246
} 
dan memiliki psikologis masyarakat sendiri. ${ }^{22}$ Sejarah sosial dan psiko-sosial mengambil peran disni. Teks tidak akan terlepas dari konteks situasinya, dan inilah yang disebut dengan dialektika al-Qur'an. Dialektika selallu memainkan tiga konteks situasi: (1) Medan wacana, yakni hal-hal yang sedang terjadi dan pada sifat sosial yang sedang berlangsung. (2) Pelibat wacana, yakni orang-orang yang terlibat, sifat, kedudukan, serta peran mereka. Dan (3) Sarana wacana, yakni bagian yang sedang diperankan oleh bahasa dalam situasi itu. ${ }^{23}$

\section{Masyarakat Arab: Perspektif Sejarah Sosial}

Sub bab ini akan melihat realitas sosial dengan pendekatan sejarah sosial. Membahas beberapa faktor yang membentuk psikis dan spritual masyarakat Arab. Karena psiologis dan spritual terjadi karena adanya dorongan yang berhubungan dengan kebutuhan psikis dan spritual manusia. ${ }^{24}$ Sejarah mengabadikan narasi, mencatat bangsa Arab memiliki letak geografis sebagai yang kurang beruntung. Himpitan kemajuan negara tetangganya membuat Arab menjadi negara yang terbelakang. ${ }^{25}$ Tidak heran, Arab di masa lalu pun identik dengan sebuah kultur Jāhiliyah. Tidak memiliki kesatuan politik, sebagian besar penduduknya merupakan komunitas yang memiliki kebiasaan berpindah-pindah (nomaden). Letak geografis ini berpengaruh pada karakter, ${ }^{26}$ cara pandang terhadap kehidupan, baik secara individual maupun kolektif.

Kegemaran masyarakat untuk melakukan pengembaraan dari satu tempat ke tempat lain jelas menuntut suatu keberanian. ${ }^{27}$ Keberanian dalam maksud negatif. Mereka tidak mengenal perdagangan maupun pertanian, yang mereka kenal hanyalah menyerang, membalas serangan, merampok, dan menjarah. ${ }^{28}$ Mereka berbicara dengan dialek keras dan kasar. Secara sosiologis, tekanan populasi yang berkepanjangan menyebabkan masyarakat sering melakukan tindakan "biadab" dalam rangka mempertahankan eksistensi keluarga dan kehormatan sukunya. Kondisi geografis membuat mereka hidup secara bersaing, membuat kelompok masyarakat berdasarkan suku dan kabilah. ${ }^{29}$ Kehidupan secara bersuku-suku yang diikat dengan pertalian darah (etnis) menyebabkan

\footnotetext{
${ }^{22}$ Mahsun, Metode Penelitian Bahasa: Tahapan, Strategi, Metode, dan Tekniknya (Jakarta: Raja Grafindo, 2007), hlm. 229.

${ }^{23}$ Halliday Ruqayya Hasan, Bahasa, Konteks, dan Teks ..., hlm. 16.

${ }^{24}$ Muhammad Utsman Najati, Psikologi Qur'ani; Dari Jiwa Hingga Ilmu Ladunni terj, Hedi Fajar (Bandung: Marja, 2010), hlm. 30

${ }^{25}$ Ayzumardi Azra (dkk),"Masyarakat Arab Pra-Islam”. ..., hlm. 12.

${ }^{26}$ Ibid., hlm. 19.

${ }^{27}$ Ibid., hlm. 20.

${ }^{28}$ Wildana, Sastra Arab dan Lintas Budaya ..., hlm. 31.

${ }^{29}$ Kuntowijoyo, Paradigma Islam . . . , hlm. 293.
} 
mereka hidup eksklusif. ${ }^{30}$ Tidak ada standar baik dan buruk (etika) dalam mempertahankan di tengah-tengah iklim dan kondisi sosial padang pasir yang kejam.

Sistem kepemipinan dan politik, dijalankan dengan mengembangkan sistem oligarki. Pembagian kekuasaan ditujukan pada bidang-bidang tertentu. ${ }^{31}$ Praktik oligarki ini menyebabkan terjadinya kesenjangan ekonomi. Di satu sisi, terdapat para aristokrat kaya, di sisi lain, terdapat kaum miskin yang tertindas. ${ }^{32}$

Iklim padang pasir yang kejam menuntut keberanian menjadi tuntutan hidup yang tidak bisa ditawar. Kehidupan menjadi penuh dengan kekerasan dan pertentangan. ${ }^{33}$ Semangat kesukuan ('ashabiyyah) menjadi ajang adu kekuatan. Bahkan dikenal dibudaya mereka adat hutang darah, yaitu pengenaan kewajiban kepada salah seorang anggota keluarga korban pembunuhan untuk menuntut balas kepada pelaku pembunuhan. ${ }^{34}$

\section{Psikologi Sosial dan Pola Pikir Masyarakat Arab Terhadap Agama}

\section{Psikologi Sosial}

Secara umum dan terlepas dari karakteristik positif orang Arab pra-Islam. Karakteristik orang-orang Arab pra-Islam yang muncul dari sikap komunalisme diatas, ${ }^{35}$ digambarkan oleh al-Qur'an dengan karakter psikologi sosial yang penuh dengan kezaliman, selalu bermusuhan. Mereka selalu ingkar janji, menipu, mengikuti hawa nafsu serta tidak bisa mengendalikan emosi. ${ }^{36}$

Salah satu teori psikologi modern mengatakan, dorongan psikologis diproleh dari dorongan fisiologis (biologis), yang tidak dapat dilepaskan dari faktor pertumbuhan sosial. ${ }^{37}$ Dorongan ini banyak membentuk psikologi sosial masyarakat. Membaca bagaimana faktor singkat diatas, sangat mempengaruhi psiko sosial masyarakat Arab. Psiko-sosial masyarakat Arab tercatat banyak dihabiskan pada kebutuhan dunia. Sedikit diantara mereka bisa mengimbanginya dengan kebutuhan spritual. Bahkan orang taat bergama dari mereka tak ayal mengasingkan diri ke goa, hanya untuk mendapatkan ketenangan.

\footnotetext{
${ }^{30}$ Taufik Adnan Amal, Reskonstruksi Sejarah al-Qur'an (Yogyakarta: FkBA, 2001), hlm. 12.

${ }^{31}$ Muntaha (dkk.), Pemikiran dan Peradaban Islam (Yogyakarta: UII Press, 1998), hlm. 24

${ }^{32}$ Azyumardi Azra (dkk), "Masyarakat Arab Pra-Islam”.., hlm. 21. t.th.), hlm. 15 .

${ }^{33}$ Hassan Ibrahim Hassan, Sejarah dan Kebudayaan Islam (Yogyakarta: Kota Kembang,

${ }^{34}$ Bernard Lewis, Bangsa Arab dalam Lintasan Sejarah terj. Said Jamhuri ( Jakarta: Pedoman Ilmu Jaya, 1988), hlm. 11.

${ }^{35}$ Muhammad Syahrur, Tirani Islam ..., hlm. 66.

${ }^{36}$ Muhammad Utsman Najati, Psikologi Qur'ani ..., hlm. 30.

${ }^{37}$ Ibid., hlm. 30
} 
Mengedepankan emosi telah membuat kehidupan spritualitas mereka tidak stabil, agama tidak sejalan dengan karakter kemanusiaan mereka. Psiko-sosial mereka tidak mempan untuk dimasuki agama. Karena agama membutuhkan kematangan individu, dan keseimbangan mental dalam menghayatinya. ${ }^{38}$

\section{Pola Pikir Terhadap Agama}

Beragama memang membutuhkan dorongan fitrah manusia, dorongan naluri untuk ber-tadayyun. Namun, dorongan ini pula tak lepas dari realitas keberadaannya. Keberagamaan masyarakat Arab menggunakan banyak istilah dalam al-Qur'an. Namun, al-Qur'an banyak menyebut mereka dimasa awal islam dengan kaum musyrikūn, yang melakukan pemujaan kepada bulan, matahari pohon-pohon. Mereka ini disatu sisi disebut jug ummi, masyarakat yang tidak memiliki kitab suci, sebagai negasi dariahl kitāb. ${ }^{39}$

Psiko-sosial masyarakat Arab diatas, menegaskan pada simpulan bahwa agama yang mereka anut adalah agama bumi (din al-ardli). ${ }^{40}$ Fakta mereka yang menyembah banyak tuhan (يَتَّخِنَ أَرْبَابا), mendekati pada kenyataan bahwa agama ini lahir atas produk pemikiran orang Arab, yang didasarkan atas kondisi dan kepentingan mereka. ${ }^{41}$ Pola fikir terhadap agama dimaksudkan melihat pandangan mereka menganai agama.

Masyarakat Arab menjadikan berhala itu sebagai bentuk taqarrub kepada Allah dan bentuk keagamaan ini disebut Watsāniyyah. Kepercayaan animisme lokal, banyak terdapat di Arab Tengah dan Arab Barat. Jika melihat faktor sejarah sosial diatas, hal ini sangat terkait dengan sifat hidup mereka yang tergantung sepenuhnya kepada alam. ${ }^{42}$ Dalam benak mereka, alam diwarnai oleh kehidupan makhluk lain yang memiliki kekuatan. Mereka juga mempunyai dewa-dewa alam yang terkait dengan penghidupan mereka. Bahkan bagi masyarakat Arab, jin adalah sekutu Tuhan dalam mengatur kehidupan. ${ }^{43}$

Pola pikir mereka terhadap agama beragam karena ketergantungan pada alam dan kehidupan. Faktor duniawi ini yang paling dominan merubahn psikologis mereka. Mereka berjanji, bersyukur namun dengan cepat pula berbuat aniaya (Q.S Yunus 22-23). Mereka pula sering berdoa namun kembali

\footnotetext{
${ }^{38}$ Ibid., hlm. 31

${ }^{39}$ Muhammad Galib, Ahl Kitab: Makna dan Cakupannya (Jakarta: Paramadina, 1998), hlm. 27.

${ }^{40}$ Aflatun Muchtar, Tunduk Kepada Allah; Fungsi dan Peran Agama Dalam Kehidupan Manusia, (Jakarta, Khazanan Baru, 2000), hlm. 8

${ }^{41}$ Aflatun Muchtar, Tunduk Kepada Allah ..., hlm. 8.

${ }^{42}$ Ali Sodiqin, Antropologi Al-Qur'an ..., hlm. 48.

${ }^{43}$ Aflatun Muchtar, Tunduk Kepada Allah ... , hlm. 33-34.
} 
pada kemusyrikan (Q.S al-Ankabut 65). Begitu cepat berubah semuanya, karen sandaran agama adalah kehidupan dunia. ${ }^{44}$ Pola fikir ini membuat mereka beragam terus, namun disatu sisi akan melakukan pelanggaran terus. Tidak ada bekas agama dalam pola fikir dan pengendalian hati mereka. Beragama menjadi tanpa keahdiran Tuhan.

Tradisi yang mendarah daging telah mengaburkan bahwa mereka pernah menerima ajaran-ajaran samawi. Pandangan hidup yang materialisme diekspresikan dengan membuat patung-patung sebagai simbol kehadiran tuhan mereka. Ajaran samawi telah menjadi asing dan usang di telinga mereka, sehingga tidak mengherankan ketika Muhammad mendakwakan sebagai nabi menjadi bahan tertawaan, meskipun otoritas kearifan dan kejujuran Muhammad telah diakui oleh masyarakatnya.

Sikap materelistik ini telah membauat pandangan mereka terhadap agama menjadi kebutuhan yang simbiosis mutualistik, bukan keheningan dan kesadaran diri. Merekalah käfirun, bukan mukhlisūna lahu ad-din. Mereka memiliki banyak patung, dewa yang bisa saja mereka hadapin kapanpun mereka mau dan melaporkan keinginan (doa) nya kepada dewa tertentu. Pribadi yang egois dan matrealistis ini berbanding lurus dengan moralitas, menjadi kaum rendah dan jatuh pada lembah hawa nafsu. Dan menyembah tuhan karena nafsu keduniaan yang diinginkannya. ${ }^{45}$

Mereka melakukan pemujaan agama, namun tetap melakukan kemusyrikan. ${ }^{46}$ Mereka telah merusak pola fikir beragama. Bahkan setelah Islam datang pun kakter dan sikap mereka masih banyak dipertahankan. Al-Qur'an menggambarkan mereka dengan pribadi sombong dan membangkang terhadap kebenaran (أَبَى وَاسنتَكْبَرَ), mengolok-olok rasul dan menuduhnya tukang sihir

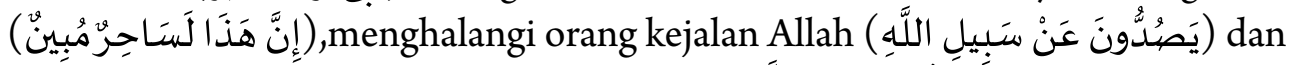

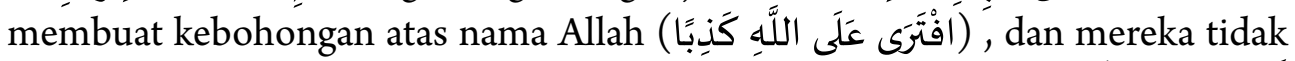

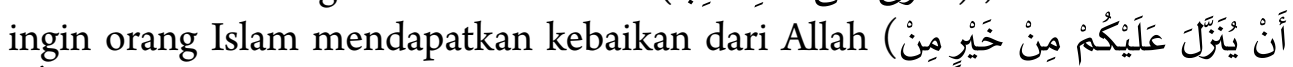
(رَِّكمَم (1). Hal in terjadi kebanyakan diawal graduasi wahyu, walaupun tidak semu karena ada juga golongan hunafa' yang masih kuat memegang tradisi ibrahim. ${ }^{47}$

\footnotetext{
${ }^{44}$ Ibid, hlm. 33-34.

${ }^{45}$ Muhammad Utsman Najati, Psikologi Qur'ani ... , hlm. 30

${ }^{46}$ Toshihiko Izutsu, Relasi Tuhan dan Manusia ... ., hlm. 107

${ }^{47}$ Aflatun Muchtar, Tunduk Kepada Allah ... , hlm. 77
} 


\section{Dialektika al-Qur'an Dalam Mengubah Pola Fikir Masayarakat Arab Terhadap Agama}

Sadar akan pengalaman, dan penghayatan kehidupan yang dilakukan oleh Muahaamd saw sebelum diangkat menjadi Rasul, Allah memerintahkan untuk mennguanakn metode persuasif dalam mengajak masyarakat Arab memeluk din al-isläm. Dan untuk mengubah pola fikir agam mereka yang sebelumnya din alardli menjadi din ak-haqq.

Ada bebrapa langkah yang digunakan Nabi dalam berdakwah, dengan selalu memperhatikan realitas komples, termasuk spiko-sosial mereka:

\section{Menyampaikan Ajaran Dengan Dialog (Hiwār)}

Daialog adalah cara pertama yang ditempuh Nabi. Kenapa tidak lansung memberontak dan tegas merubah? Nabi jelas lebih memahami bagaimana cara menyadarkan mereka. Realitas kehidupan yang sulit membuat mereka kuat dan sering bertindak konfrontatif. Apalgi emosi dan psiko-sosial mereka yang tidak stabil.

Pegangan pengalaman beliau yang cair dengan masyarakat membuat cara pertama yang ditempuh adalah melakukan dialog secara cair. ${ }^{48}$ Dalam al-Qur'an, Allah menarasikan bahwa kata hiwār mengandung indikasi dialog yang sejajar -dari segi starata-, dengan suasana cair -tanpa ada rasa canggung-, masingmasing pesertanya kooperatif dan bersedia kembali ke kebenran jika sikapnya salah. ${ }^{49}$ Realitas yang tidak stabil secara sosial dan psiko-sosial, menjadi lebih lunak untuk menyampaikan ajaran al-Qur'an dengan cara yang lembut. Q.S ali Imran ayat 159:

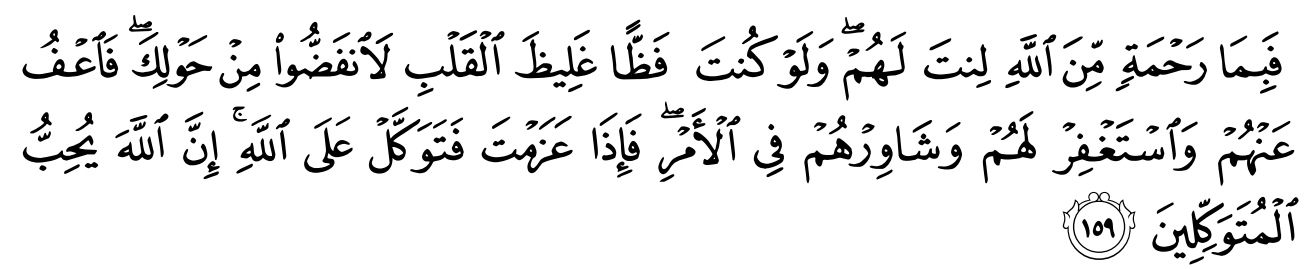

Selain itu, tercatat ada beberapa pola fikir agama yang dirubah oleh nabi dengan cara hiwär ini, anttara lain:

\footnotetext{
${ }^{48}$ Mukhlis Hanafi, Moderasi Islam (Jakarta, Pusat Studi Qur'an, 2013), hlm. 187-193

${ }^{49}$ Ibid., 187-193.
} 


\section{a. Fitrah Agama Monoteis}

Q.S Al-Imran ayat 64

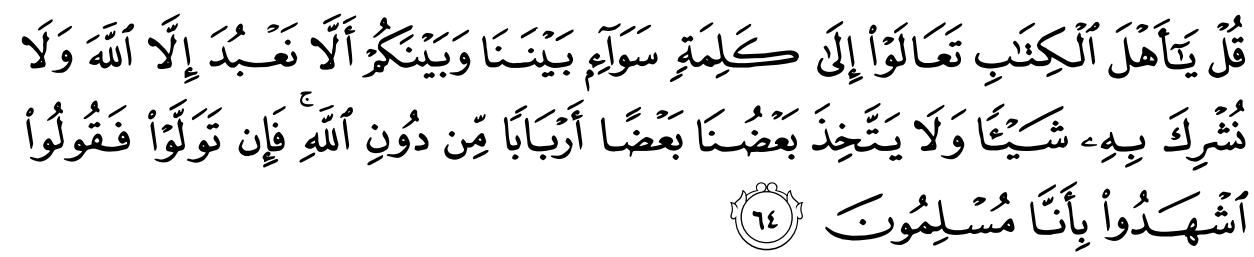

Dalam upaya "menyadarkan" kekeliruan yang mereka buat al-Qur'an lebih menggunaka pendekatan yang bertahap dan perbandingan. Bedialog untuk menjelaskan mana yang benar dan mana yang baik, serta mana yang sebaliknya. Semua disampaikan melalui nasihat dan bimbingan yang arif dan bijaksana. ${ }^{50}$

Tema ini pertama disampaikan dnegan dialog karena melihat realita yang tidak mudah ditaklukkan, butuh waktu dan kesabaran untuk sedikit menggeser pola fikir mereka terhadap agama. Dialog ini dilakukan sesuai dengan tingkat pemahaman mereka, sehingga lebih mengena dan bermanfaat. Artinya pola pemahaman agama yang fundamental ini disampaikan sesederhana mungkin, dengan bergerak secara dialogis pada dataran pemahaman keagamaan tingkat masyarakat bawah. Dalam Q.S ar-Rum ayat 30, Allah juga menegaskan tema awal wahyu Muhammad saw kepada masyarakatnya, agar mengajak kepada agama fitrah.

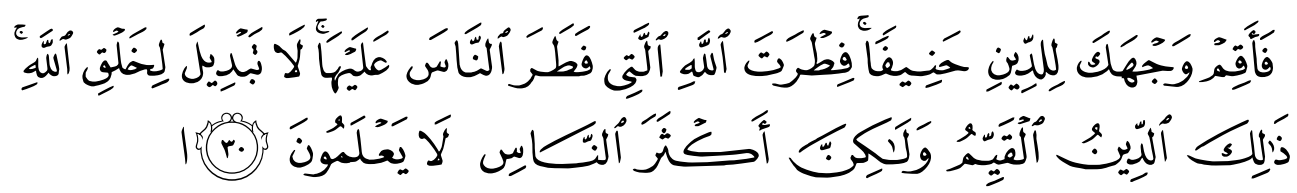

Jika diperhatikan khitāb nya, ajaran tauhid ini banyak menyentuh keberagamaan kelas bawah. Ayat yang banyak turun dimasa awal ini mengenai kisah kisah nabi terdahulu, seperti; Nabi Yusuf, Nabi Sulaiman, Nabi Musa dan kisah lainnya. Penurutan kisah ini jelas memuat ajaran dakwah, alur kisahnya akan menjadi stimulus yang dapat membentuk kepribadian bertauhid dan humanis, ${ }^{51}$ bagi mereka yang masih berada dalam keberagamaan awam. Tugas Nabi menag menyampaikan tauhid yang menjadi ajaran fundamental, bahkan ini menjadi misi dari semua Nabi.

\footnotetext{
${ }^{50}$ Aflatun Muchtar, Tunduk Kepada Allah ... , hlm. 146-147

${ }^{51}$ Zuhrui, Kiprah Politik Rasulullah ..., hlm. 26
} 


\section{b. Agama Dan Nilai Kemanusiaan}

Ajaran fitrah agama adalah mengedepankan karakter kemanusiaan. Ajaran Alī-Imran [3]: 110 disebutkan dan al-Baqarah ayat 62 :

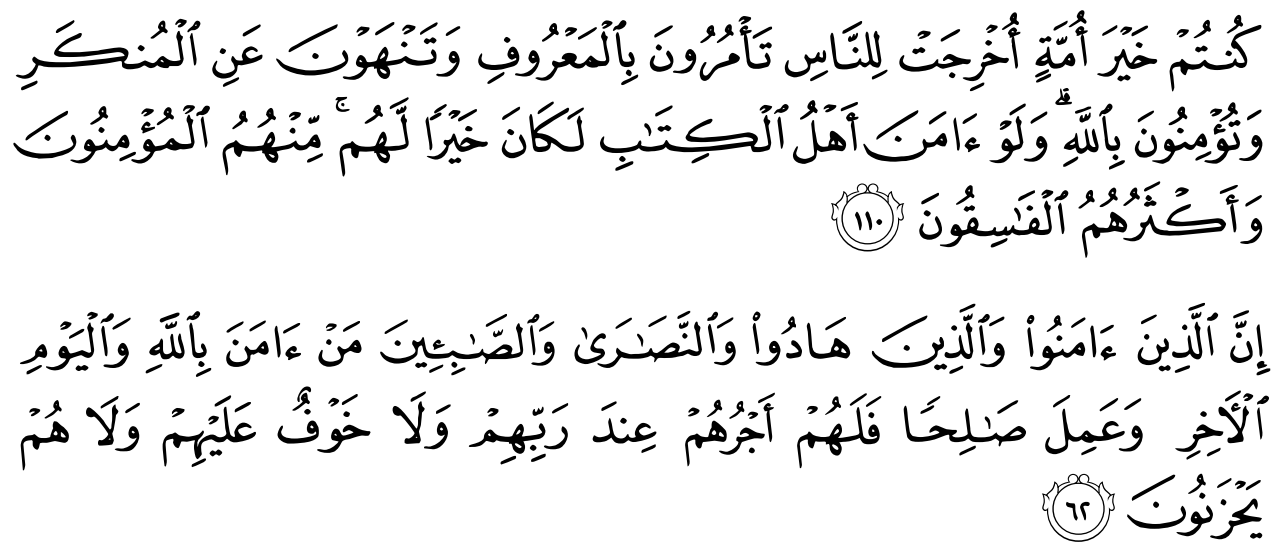

Ayat ini menekankan pada ahubungan penting antara bertuhan dan berbuat melakukan humanisasi ditanah Arab. Berpegang pada prinsip dasar alQur'an, seperti, keadilan, kejujuran, solidaritas kemanusiaan dan persamaan,. Semangat yang dibawa dalam humanisasi ini adalah membawa manusia kepada tempat selayaknya yang ditempati oleh manusia dan membawanya kembali kepada fitrah, yaitu kesadaran terhadap ketuhanan, dan manusia sebagai makhluk individu dan sosial.

Disinilah nilai persamaan yang dibawa al-Qur'an dalam proses perubahan paradigma realitas Arab pra-Islam. Bahkan jika melihat narasi al-Qur'an dalam surat al-Baqarah, bukan hanya penyadaran yang diberikan adalah pentingnya beramal sholih atau berbuat baik. Bahkana konsep Taqwa -untuk selanjutnya menjadi Muttaqin- dalam Islam sesungguhnya berperan disana. Orang yang Muttaqin tidak hanya memiliki pola berfikir agama hanya untuk ketaannya kepada Allah sebagai pahala untuk dirinya semata, namun juga ketaatan kepada Allah yang bisa memperbaiki prilaku diri, dan dirinya baik bagi orang lain. Paling tidak, amal yang dilakukan tidak terlalu "ego" terorientasi pada pahala. Muslim-Muttaqin adalah mereka yang shalih dan mushlih, yang beragama dengan melaksanakan ibadah kepada Allah, ditransformasikan penghayatannya pada diri sendiri dan diorientasikan pengamalannya pada orang lain. Mengesampingkan salah satu dari tiga sisi ini tidaklah akan sampai sempurna pada derajat tersebut. ${ }^{52}$

\footnotetext{
${ }^{52}$ Q.S al-Fatir ayat 32,
} 
Al-Qur'an mengajarkan bahwa perbedaan bukalan permusuhan, pun itu perbedaan keyakina. ${ }^{53}$ Paradigma al-Qur'an dalam proses humanisasi kaum Arab telah merubah segala sesuatu yang tidak memiliki nilai-nilai sejati insaniyyah dehumanisasi, agresivitas kolektif - dengan mengembalikan pada tempat yang seharusnya manusia miliki sebagai manusia bukan manusia sebagai hewan dan makhluk lainnya. Dalam tingkat psikologi, al-Qur'an telah melakukan pergeseran kejiawaan masyarakat Arab dari an-naf al-ammara' bi as-su' menuju an-nafsu allawwamah. Setidaknya dalam proses hiwär ini Muhammad saw menyadarkan diri mereka dan memrintahkan mereka untuk menyesali diri, merenung dan sedikit menyapa jiwa mereka.

\section{Menyampaikan Dengan Jalan Debat Argumentatif (Jidāl)}

Dalam penyampai secara Jidāl, Nabi Muhammad saw juga melihat psikologi lawannya. Tentu mereka adalah kalangan elit agamawan Arab dan lainnya yang memiliki dan disegani oleh orang Arab. Mereka adalah orang yang dimuliakana, para penyair juga dimasukkan dalam kategori ini. Menghadapi kaum ini, Q.S an-Nahl ayat 125 menjelaskan.

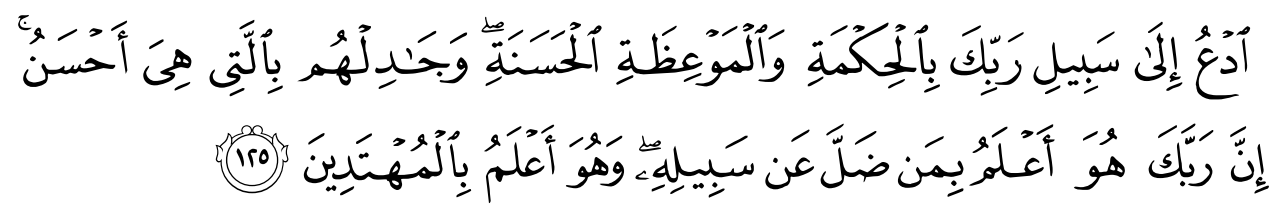

Ayat ini menegaskan, bahwa dalam melakukan diwajibkan dengan dua pilihan, dengan cara yang baik dan cara yang lebih baik. ${ }^{54}$ Kata hikmah menunjukkan pada orisinalitas ajaran, dan penyadaran dalam diri Nabi bahwa dakwah adalah proses, bukan hasil. Ini sebenarnya langkah pertama yang diserukan kepada Nabi. Jika tidak berhasil, maka disarankan menggunakan jalan jidāl, yaitu dengan melakukan debad argumentatif, mematahkan argumen lawan. Jidal disebut juga dengan perang argumentasi, bukan kontak fisik.

Nabi sadar bahwa misi suci wahyu ini ingin memperbaiki moralitas masyarakatnya yang rusak itu dengan berdialog secara argumentatif, 'aqliyah, dan bijak, hikmah, sera mengajak umat yang "tak beradab", jähilliyah, ini ke jalan yang berkeadaban, madāniyyah. ${ }^{55}$ Karenanya kehadiran al-Qur'an juga untuk

\footnotetext{
${ }^{53}$ Q.S Al-Hujrāt [49]: 13

${ }^{54}$ Aflatun Muchtar, Tunduk Kepada Allah ... , hlm. 147

${ }^{55}$ Umar Shihab, Kontekstualitas al-Qur'an Kajian Tematik atas Ayat-Ayat Hukum dalam alQur'an (Jakarta: Penamadani, 2005), , hlm. 23.
} 
merubah pola fikir sosial masyarakat Arab, termasuk merubah apa yang disebut dengan hukm al-Jahiliyyah. ${ }^{56}$

Karena itu dalam berbedebad, yang dikedepankan adalah dalil yang jelas (al-hijaj an-nirā̄ì), argumentasi yang jelas (al-barāhin al-bayyinah). Sehingga perdebatan menghasilkan konstruksi dan argumentasi yang benar, tidak menyalahkan. Dalam al-Baqarah dikatakan "hätu burhānakum in kuntum shädiqin”.

Ada banyak tema yang didebatkan dalam masalah ini, dan tentu tidaklah mencukupi jika disebut panjang dalam artikel ini. Salah satunya adalah menolak an-nafs al-ammarah bi as-su' mereka terhadap dunia. Al-Qur'an mengajak mereka agar menjadikan dunia ssebagai jalan menuju akhirat. Masalh lain yang diperdebatkan adalah hukum itu dalam ruang lingkup ekonomi adalah bentuk riba. Dari yang awalnya bersipat penjajahan, al-Qur'an datang dengan mengatur segalanya. Dan banyak tema lainnya, seprti: penciptaan al-Qur’an, kepemimpinan, dsb.

Dalam catatan sejarah, semua hal ini dimenangkan oleh Nabi, mereka hanya tidak mengakui saja walaupun argumentasinya terbantahkan. Sebagaimana tujuan hiwär, maka dalam penyampaian secara jidăl pula nabi hanya bersaha mengantarkan dan meperbaiki mereka secara psikologis. Mengajak mereka merenung, menghayati agama.

Obyek yang sama namun metode dan cara berfikir berbeda, maka hasil yang dicapai pun bisa berbeda. Dengan ini sesungguhnya syariat islam itu berbedan dan istimewa. Semua seruan ini termuat dalam diri beliau, peranginya untuk disampaikan dengan cara baik kepada obyek pertamanya yakni kaum musyrik, yahudi dan nasrani dan kemudia semua ummat manusia.

Poin-poin yang dikemukanan ayat al-Qur'an diatas menekankan kita pad simpulan utama, bahwa gradualisasi turunnya wahyu memberikan gambaran yang sangat penting bahwa tatanan yang hendak dibangun oleh alQur'an bukanlah merupakan paket sekali jadi yang absolud tanpa melalui proses responsif dan terpisah dari perkembangan sosio-politik yang ada. Peran Muhammad saw menjadi sangat penting dan sentral dalam kaitannya dengan masalah-masalah praktis, bahkan memiliki otoritas yang tak terbantahkan di luar al-Qur'an. ${ }^{57}$

\footnotetext{
${ }^{56}$ Surah al-Māidah [5]: 50

${ }^{57}$ Lihat QS. Ali Imran (3): 32 dan 132, al-Hasyr (59): 7, dan al-Nisa' (4): 49, 65, dan 80.
} 
Dialektika dengan basis kulturan dan melihat psikologi masyarakat setempat. Dengan memperhatikan berbagai aspek khitab nya, al-Qur'an telah menciptakan kesadaran dan persepsi yang terpusat kepada tuhan yang hidup, kreatif dan sekaligus trasenden. Melihat banyak juga diantara mereka yang sudah melakukan perenungan kepada Tuhan (hanif), al-Qur'an pun menggunakan apresiasi kebahasaanya untuk memperbaharui kesadaran keagamaan bangsa Arab dan para audiens nya yang lain.

Hingga pada akhirnya, hadirnya Muhammad saw. telah merubah pola keberagamaan an-nafs al-ammarah bi as-su' menjadi individu dengan psikologi annafs al-lawwamah, individu yang islami. Al-Qur'an menggambarkannya dengan an-nafs al-muthma'innah, jiwa yang tenang dan seimbang, tidak meninggalkan dunia sebaiknya jiwa dunianya termotivasi untuk diniatkan ibada kepadanya.

Adapun jika dinarasikan dalam bentuk diagram, perubahan dari dialektika al-Qur'an dalam psiko-sosial dan pola fikir keagamaan masyarakat Arab dapat dilihat sebagai berikut:

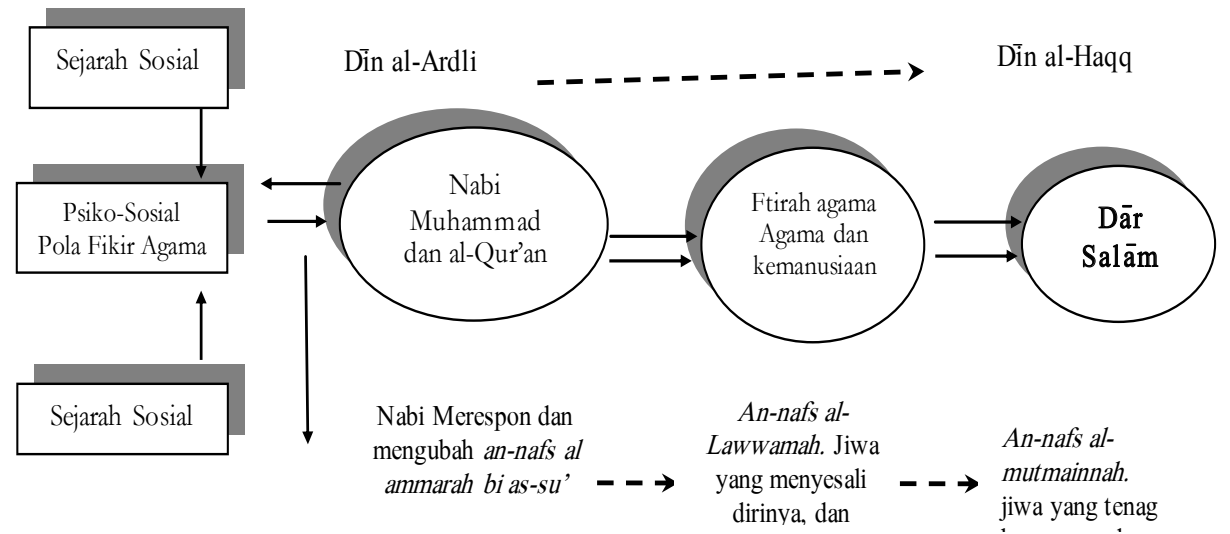

Hiwār dan Jidāl

\section{Penutup}

Al-Qur'an hadir ditengah peradaban Arab yang multikultural. Dalam perkembangannya, ia mengalami kontak sosial keagamaan baik ditingkat wacana maupun praksis. Dalam pada itu, Al-Qur'an sendiri telah menggunakan metode persuasif, dalam merubah pola fikir mereka. Oleh karena itu, Nabi (sebagai pembawa al-Qur'an) juga menerapkan gaya al-Qur'an dalam berinteraksi, yakni 
menggunakan metode berdialog, dengan cair dalam bergaul dan bertatap muka lansung dengan masayarakat. Sedikit demi sedikit Nabi menyentuh tema Tauhid, sembari juga menyentuh tema kisah-kisah inspiratif menjadi panutan mereka. Semua dilakkan dalam menghadapi kaum bawah masyarakat arab. Adapun dalam menghadapi kaum elit, Nabi menggunakan metode dakwah dengan berdebad, atau perang pendapat (jidāl), bukan perang kontak fisik. Tema tema yang diberikan Nabi berupa hukum, ketuhanan, akhirat dsb. Semua nabi berika dengan nada dialog argumentatif-konstruktif. Sehingga diantara mereka banyak yang masuk islam, walau jumlahnya tak sebanyak dengan pasca belai hijrah.

Sukses nyata dakwa Nabi adalah ketika berhasil mengubah psikologi masyarakat Arab. Dari mereka yang memiliki kejiwaan an-nafs al-ammarah bi as$s u$ ' dengan perlahan Nabi sadarkan hingga mereka merasa bersedih diri dan naik pada tingkatan psikologis an-nafs al-lawwamah. Sampai ketika mendapatkan hidayah, mereka menjadi begitu lebih tenang, arif dan mencapai derajat psikologis dengan jiwa yang tenang an-nafs al-mutmainnah.

\section{Daftar Pustaka}

Abu Zaid, Nasr Hamid. Mafhūm al-Nass: Dirāsat fì 'Ulūm al-Qur'ān, Beirut: alMarkaz al-Tsaqāî̀ al-Arabī, 2000.

Al-Baquri, Ahmad Hasan. Atsar al-Qur'ān al-Karìm fī al-Lughah al-'Arabiyyah, Mesir: Dar al-Ma'arif, 1983.

Ali. K, Sejarah Islam: Tarikh Pramodern Jakarta: Srigunting Raja Grafindo Persada, 2003.

Al-Khuli, Amin dan Nasr Hamid Abu Zaid Metode Tafsir Sastra, ter. Khairon Nahdiyyin, .Yogyakarta: Adab Press, 2004.

Alwasilah, A. Chaedar Sosiologi Bahasa . Bandung: Angkasa, 1989.

Amal, Taufik Adnan. Reskonstruksi Sejarah al-Qur'an, Yogyakarta: FkBA, 2001.

Azra, Ayzumardi (dkk). "Masyarakat Arab Pra-Islam" dalam Ensiklopedi Tematis Dunia Islam : Akar dan Awal, Komaruddin Hidayat (ed.) (Jakarta: PT 
Ichtiar Baru Van Hoeve, 2002.

Az-Zarqani, Muhammad 'Abdul-Azim. Manahilul-Irfan fi 'Ulum al-Qur'an, Beirut: Dar al-Kutub al-Arabi, 1995.

Boisard, Marcel A. Humanisme dalam Islam terj. M. Rasidji, Jakarta: Bulan Bintang, 1980.

Caron, Jean. an Introduction to Psycholinguistics London, Harvester Wheatsheaf, 1992.

Engineer, Asghar Ali. Islam dan Pembebasan, Yogyakarta: LKiS, 2007.

Faiz, Fahruddin. Hermeneutika Al-Qur'an: Tema-tema Kontroversial. Yogyakarta: eLSAQPress, 2005.

Fatawi, M. Faisol. Tafsir Sosiolinguistik; Memahami Hurf Muqota'ah Dalam alQur'an. Malang, UIN Malang Press, 2009.

Galib, Muhammad. Ahl Kitab: Makna dan Cakupannya Jakarta: Paramadina, 1998.

Hanafi, Mukhlis. Moderasi Islam (Jakarta, Pusat Studi Qur’an, 2013.

Hasan, Halliday-Ruqayya. Bahasa, Konteks, dan Teks: Aspek-aspek Bahasa dalam Pandangan Semiotik Sosial, Yogyakarta: Gajahmada University Press, 1994.

Hassan, Hassan Ibrahim. Sejarah dan Kebudayaan Islam. Yogyakarta; Kota Kembang, t.th.

Izutsu, Toshihiko. Relasi Tuhan dan Manusia terj. Agus Fehri Husein, (dkk.). Yogyakarta: Tiara Wacana Yogya. 2003.

Kermani, Navid. "From Revelation to Interpretation; Nash Hamid Abu Zayd and The Literary Study of The Qur'a>n", dalam Suha Taji-Farouki (ed), Modern Muslim Intellectuals an the Qur'a>n, London: Oxford University Press, 2004.

Kuntowijoyo, Paradigma Islam Interpretasi Untuk Aksi . Bandung: Mizan, 1991. 
Lewis, Bernard. Bangsa Arab dalam Lintasan Sejarah dari Segi Geografi, Sosial, Budaya dan Peranan Islam, terj. Said Jamhuri. Jakarta: Pedoman Ilmu Jaya, 1988.

Mahsun, Metode Penelitian Bahasa: Tahapan, Strategi, Metode, dan Tekniknya, Jakarta: Raja Grafindo, 2007.

Minhaji, Akh. Sejarah Sosial dalam Studi Islam: Teori, Metodologi, dan Implementasi, Yogyakarta: Suka Press, 2013.

Muchtar, Aflatun. Tunduk Kepada Allah; Fungsi dan Peran Agama Dalam Kehidupan Manusia, Jakarta, Khazanan Baru, 2000.

Munthoha dkk., Pemikiran dan Peradaban Islam Yogyakarta: UII Press, 1998.

Najati, Muhammad Utsman. Psikologi Qur'ani; Dari Jiwa Hingga Ilmu Ladunni terj, Hedi Fajar, Bandung, Marja, 2010.

Partanto, Pius A. dan M. Dahlan Al-Barry, Kamus Ilmiah Populer Surabaya: Arkola, 2001.

Shihab, Umar. Kontekstualitas al-Qur'an Kajian Tematik atas Ayat-Ayat Hukum dalam al-Qur'an. Jakarta: Penamadani, 2005.

Sodiqin, Ali. Antropologi Al-Qur'an: Model Dialektika Wahyu dan Budaya, Yogyakarta: Ar-Ruzz Media, 2008.

Syahrur, Muhammad. Tirani Islam: Genealogi Masyarakat dan Negara, terj. Saifuddin Zuhri .Yogyakarta: Lkis. 2003.

Umar, Mostofa. "Gradualisasi Turunnya Al-Qur’an. Tinjauan Antropologi dan Psikologi dalam Potret Pluralitas Budaya “, Jurnal Studi Ilmu-Ilmu AlQur'an dan Hadits, Vol. VI, 2005.

Zuhri, M. Potret Keteladanan Kiprah Politik Muhammad Rasulullah, Yogyakarta: LESFI. 2004. 